\title{
Analysis on the Artistic Features of Artistic Songs and Western Operas
}

\author{
Ying Zheng \\ Sichuan Conservatory of Music, Sichuan, Chengdu, 610500
}

Keywords: opera; artistic song; artistic features; comparison

\begin{abstract}
Opera is a kind of comprehensive art, and it is also the most difficult and most attractive art form. The singing style of artistic songs is more delicate, and the powerful sounds like the high-pitched area of the opera aria are less. Operas tend to be strong and straightforward, and the sound of artistic songs is light and flexible. So in many cases, singing art songs needs to be delicate, accurate and beautiful. This paper takes the brief history of the development of western opera and artistic songs as the starting point, and combs the development of opera and artistic songs, and then summarizes and compares the singing characteristics of the two.
\end{abstract}

\section{Introduction}

Opera is one of the important forms in vocal art. Opera is a kind of comprehensive art. It focuses on singing and concentrates on art forms such as symphony, drama, dance, stage art and ballet. In the field of vocal art, opera is the most difficult and most attractive form of art. The opera was born in Florence, Italy, at the turn of the 16th and 17th centuries, and was the product of the famous European Renaissance. Because the opera concentrates on the advantages of music, drama and instrumental music, it has a strong artistic expression and has become a pet of the court and nobles, which has been greatly developed. Since the beginning of the 17th century, almost all composers have loved opera creation. At the beginning of the 18th century, the development of music reached a glorious era. The digital bass-based music reached its perfect level, and produced several epoch-making great musicians: such as Italy's Scarlatti, France's La Mu, Germany's Bach and Handel. The Napoli Opera School led by Scarlatti made an important contribution to the development of the opera and established the basic form of the opera aria ABA, which dominated the entire 18th century and has influenced almost all opera creations. The development of singing skills was related to the use of singer-songwriters at that time. Boys with good sound conditions were selected for castration surgery, which preserved the range of the soprano and the physical strength of men. However, this is a violation of the true meaning of art. With the progress of human society, the singers of the monks can only be recorded in history.

Since the opera was originally born in Italy, the European aristocracy's upper class was more admired for the Italian opera because of its cultural pursuit of fashion, and that it was the original art. At the same time, the Italian language is very much in line with the needs of singing, so the opera has been created in Italian. During the Gluck period, the opera was reformed, and it was a great initiative to promote the creation of opera in the native language. Unfortunately, it was only a long time later that it really began to bear fruit. The way the opera was created at the time.

It is still firmly dominated by Italian style and Italian language. Mozart's opera is still the most popular opera. In his life, he has created many famous operas, such as "The Wedding of Figaro", "Don Vanney", "The Kindness of Tito", "The Magic Flute", etc. are all excellent operas that everyone is very familiar with. "Magic Flute" is written in German and is the most outstanding of the German operas. Mozart has created many vivid opera characters and created a new era of opera. Although these operas still serve the court nobles, he linked the opera to the lives of ordinary civilians and created a new generation of new winds.

Rossini is a pioneer of Italian romantic opera and a pioneer in the maturity of opera. He wrote such works as "The Hairdresser of Zeliya" and "William" with gorgeous techniques, beautiful melodies and aura-filled music. "Excellent opera works." These masterpieces are still the most operas on stage today. Like Rossini, the Italian opera composers Donizetti and Bellini, their 
common feature is that the melody of the work is beautiful and fascinating, requiring gorgeous and superb vocal singing skills, like "Love's Glycol" and "Lamemo "The Lucia" and "Family", all of which have the characteristics of these aspects.

At the same time as a peak, they also played a positive role in the development of vocal music. The operas of these three composers have swept the world, and they have greatly influenced the development of singing technology. The technique of vocal singing has been greatly improved. So far, the operas with the most difficult vocal skills in the world operas are still from the works of their three composers. The limits of the treble, the difficulty of the cadenza, and the continuous and loud humming are all tests for the voices. Especially for the male and female high-pitched voices, singing their works is often a challenge. Due to the demand for excellence in singing technology, the opera is becoming more and more magnificent, and this period is often referred to as the "beautiful period" of the opera.

After Rossini, Donizetti and Bellini, the representative of the Italian opera is Verdi, a monument in the history of the world's opera. Will created 26 operas in his first life, except for the first two or three operas that were slightly inferior, now Rarely staged, the remaining 20 operas are very good classics. For example, "Irnani", "Rigoletto", "La Traviata", "The Poet", "Tangkalo", "Ajda", etc., Verdi's name has almost become synonymous with opera. . The era of Verdi was born in the revolutionary era of the Italian liberation movement. Therefore, his opera is full of the power of the national liberation movement. Especially in the first half of the career, this power inspired the Italian people to fight for independence. Will's first life was inspired by this heroic ideology. The heroic opera theme runs through his entire creative career and has achieved a thrilling effect in the final "Aishida" and "Othello".

Realist style operas are more shocking than romantic operas. If the romantic late operas represented by Verdi give people spiritual noble and shocking words, then realist style operas make people feel from the senses. Get more intense stimulation. Realist operas often portray love operas closer to our lives. In fact, we can also see the shadow of this style from the earlier "La Traviata" and "Carmen". Another representative in the history of opera, Puccini, is a typical lyrical opera writer. His operas are beautiful and charming, although some works such as Tosca are also marked with authentic imprints. But most operas are romantic and lyrical.

\section{The Singing Characteristics of Operas in Different Periods}

As the most representative art form in vocal art, opera needs to fully pay attention to the fact that the operas of different periods of singing should be different in the use of sound. For example, singing operas in the 17th and 18th centuries, the sound requires elegance and roundness; the breath requirements are stable, the ups and downs can't be too big; the tone color can't be excessive; the strength and weakness can't be intense; the speed of the contrast is not as exaggerated as modern. In particular, strong sounds are absolutely not as strong as modern music. This is the characteristic of the times, and is the result of factors such as the cultural environment, the natural environment, the social environment, the rhythm of people's lives, and the state of science. In the 17th and 18th centuries, in addition to the gentleness of the intensity of the opera and the songs, the speed is also of the era, and the relative amplitude is small. We often sing the works of this era very quickly and are very angry. When singing opera works of different periods, pay attention to the use of different styles of sound technology. The romantic period is more exaggerated than the classical period. The amplitude of the sound changes, the intensity changes, the timbre changes are more abundant, and the acting requirements are higher. The opera of realism style is more exaggerated than the performance of opera in the romantic period, the use of sound changes more, and there are more and more performance requirements such as shouting and hysterical crying on the stage. Therefore, we are required to choose the characters suitable for our own voices according to the characteristics of our voices, and always pay attention to protect our own voices.

In Mozart's opera, we can already hear the powerful singing of the male and the bass. In the Rossini opera, you can already hear the heroic tenor. During the Verdi period, because opera was strongly influenced by social and political movements, opera works often reflected the theme of 
national liberation and the pursuit of independence and freedom. Also, due to the fundamental changes in singing technology, after the singer's singer was abolished, the true male singing made the opera's dramatic performance more intense. The color of each part of the opera was more abundant, and the change of sound also conformed to the development trend of the times. The heroic theme, the romantic theme, the character expression required for character shaping far exceeds the original voice requirements, and the requirements for singing ability have increased, such as "Aida", "Othello", "Rigoletto" The requirements of sound technology in operas are no longer the high and low sounds of the saga, but the depth of the expression of thoughts and emotions. Therefore, when singing Verdi's operas and Italian operas throughout the romantic period, the intensity and change of the voices are obviously not the same as those of the operas of the 17th and 18th centuries and the operas of the Mozart period. Changes in amplitude, intensity, and color need to bring about the development of singing, atmosphere, language, music, and character shaping. On the other hand, as the compilation of the band has been expanded, the performance of the instrument has improved, the volume has increased, and the technique of singing has to keep up with development, otherwise the singing will be overwhelmed by the band's huge sound. Therefore, the sound must have great plasticity and explosive ability, and can express sudden and intense emotional conflicts and heroic characters.

In the realist period, the singing method of opera is more exaggerated than that in the romantic period. Of course, the basic singing state should be strictly maintained. However, sometimes there are some ways that can't appear in traditional singing due to the needs of the plot. For example, in the second act of Tosca, the painter was tortured behind the scenes. Many of the records heard real yelling. The same screaming voice can also be heard in "Country Knight". The last cries of Neo's "wearing costumes" sings seemed to be expressed in real voices, otherwise they could not reach the strong emotional diarrhea that was needed at the time. As far as the singing method is concerned, the most fear is not to use sounds in the singing state, such as shouting, crying and other non-singing vocals, which makes it easy to fatigue the voice. However, this kind of hysterical emotional eruption is needed in the real time, so when we sing these works, we need to calmly arrange our own voices and changes, and we can't just damage the vocal muscles or vocal cords.

Opera and literature are inextricably linked. The scripts of most operas are adapted from world famous works, and some are directly based on the Bible, epics, historical stories, legends and so on. Of course, a very important part of it is the adaptation of world-famous dramas, such as Shakespeare, Hiller, Hugo, Pushkin's drama is a favorite source of opera composers. Therefore, in the process of vocal music teaching, in the process of contacting and learning opera, we need to understand and read research.

Guan's literary works, studying the art and scholarship of other music and art in that era, can't sing a few arias in isolation, and even a few high notes can be learned opera. There are many depictions of the characters in the literary works. There are many operas that cannot express clear thoughts and emotions. Through research and study, it is very helpful for us to learn vocal music and learn opera.

\section{Review of Western Artistic Songs}

Art songs are an important part of the vocal art treasure house. The so-called art songs, one is specifically German songs in the romantic period; the other concept is the songs of relative folk songs, operas, religious songs, children's songs, chorus songs, in modern society.

There will be different songs and popular songs from the masses. It should be a form of music with its own characteristics. This meaning is more extensive and is not limited to German songs in the romantic period. In the long medieval period, music was greatly influenced and controlled by the church culture. It formed the rigorous and serious style of the church music and the technique of excellence. The level of vocal music reached a very high level, and at the same time produced countless excellent religious songs, medieval art. The song conforms to the trend of historical development, the mind and emotion have been liberated, the creative methods and singing methods have also changed. People are no longer limited to religious thoughts in the content of songs, but 
can face a broader emotional world. Emancipation is comprehensive, especially since the Italian Renaissance, the nations of the world, especially the European countries, have carried out an unprecedented revolution in the field of thought in various fields, which is necessarily due to social, political, scientific and technological Caused by the revolution. This topic is relatively big, we are here

Not to start, but when guiding students to study the history of music development, study the history of literary thoughts, and study the cultural styles of different societies in different eras, they should be guided to not be limited to a relatively narrow model of music or culture.

Within the circle, we should study music and study vocal music in a far-reaching sense with a broader perspective.

No matter which new epoch-making thought trend or artistic trend is formed, literary works and paintings and sculptures always show a new trend of thought. Music art is intangible and has more abstraction. It is often difficult to turn a certain trend of thought, art or aesthetic into an abstract sound art. Therefore, music often responds to new trends of thought more than literature, art, etc. The tangible art is slower. However, after all, the changes of the times have caused musicians to rush out of the long imprisonment, with beautiful ideals and beliefs, and reached the peak in the romanticism. For music art, it may be an unprecedented period. A variety of art forms bloom in full bloom and compete. Lied, represented by Schubert, Schumann, Liszt, Mendelssohn, Brahms, etc., is an era of unprecedented prosperity for art songs, such as Goth, Schiller, Heine and other great writers. There are countless beautiful poems for songwriting. Goethe's "Margaret next to the spinning wheel", "Wild Rose", "The Devil", Heine's "Wings of the Songs", ", Parting", Schiller's "fishing boy", Hugo's "When" I am dreaming, Muller's "Violet", and so on. Only Gothic's "Migned Mother" has been composed of more than 100 songs and operas by world famous musicians such as Beethoven, Schubert, Schumann, Liszt, Tchaikovsky, and Schubert's "Winter Tour". "The beautiful miller girl" and other sets are all from Muller's poetry.

Romanticism pursues lofty ideals and passionate and profound emotional expressions, and the pursuit of individualized expressions is often sentimental and touching. Because of the advantages of lyrics content, songs are easier to understand and directly reflect the psychological, emotional or natural scenery, and are closer to the world of people's thoughts and emotions in expressing subtle psychological changes and emotions. Therefore, compared with the musical forms prevailing in romantic periods such as symphony and symphonic poetry, artistic songs are of course more easily understood by people. In the romantic period, music art is full of influence and influence, which also promotes the development of song art. The emotional world of artistic songs is colorful, laissez-faire, and unrestrained. Art songs have entered a period of rapid development in such an environment. Especially in the German and Austrian regions, the masters of music represented by Schubert have created countless songs, forming a form of song with distinctive personality characteristics. The songs of this period are often referred to as art songs, and some people call it "German art songs". The famous music theorist Paul Henry Lange said: "Since the Schubert period, German art songs have occupied such an important position in the world music literature, and its name 'Lied' has been widely recognized and used in other countries. In the national language, 'Song' as English or 'Chanson' in French is not enough to describe its characteristics."

\section{The Characteristics of Artistic Songs and Comparison with Opera}

Generally speaking, the singing style of artistic songs is relatively delicate. The powerful sounds like the high-pitched area of the opera aria are relatively few. In many cases, soft sounds are needed. Therefore, the control of the breath should be appropriate, not too fierce, and the toughness should be strong. The strength of the throat space should also be moderate. Operas tend to be strong and straightforward, and the sound of artistic songs is light and flexible. So in many cases, a singer who can sing a good opera is not necessarily able to sing the perfection of the art song, because it requires necessary adjustments to the throat muscles and breathing state. Of course, singers who are good at art songs want to sing operas, the difficulty of sound is greater, and it is necessary to increase the intensity of sound and the energy of breathing, the energy of resonance, etc. 
If you don't want to adjust, you can adjust it. You need to strengthen your exercise. The singing of German art songs and the singing of artistic songs of other nationalities still have differences in the state of singing and singing brought about by the difference in style. German art songs are subtle, introverted, poetic, sound requires mellow, emotional changes are small, emotions are more delicate, small movements are more, lines are beautiful but often lack momentum; Italy also has many beautiful art songs, their singing is more enthusiasm The ups and downs, the feelings are very exaggerated, which is closely related to the character of the Italian nation. The reason why operas are produced in Italy and not in other countries, there are also reasons for this. Therefore, singing Italian-style art songs requires more passion and romance, and the sound changes can be stronger. The Spaniards can understand more than half of Italian, so Spain, like Italy, has many world-famous singers. Among the three most famous tenors in the world today, two are Spanish, and there are great singers like Kabaye and Berganza.

Art songs and operas are closely related and different. Each art song is an independent individual. A song expresses a relatively complete thought, emotion or plot. In each song, it is necessary to accurately and comprehensively express or depict emotional scenes. Art processing needs to be more precise and accurate. Of course, another form of songs, the vocal set, is a whole, which is a whole that is linked by some songs. Like Schubert's "Winter Journey", "Beautiful Mill Girl", Schumann's "Women"

People's Love, "Myrtle", Mahler's four vocal sets, Wolf's "Spanish Song Collection 10", "Italian Collection" set and so on. In the use of singing sounds, artistic songs are also different from operas. Operas are often staged in relatively large theaters. The stage is huge. The huge volume of the symphony orchestra rises from the orchestra and builds a thick sound wall to sing. In front of the home, there are thousands of listeners in the theater, and the singer needs enough volume to pass the band to ensure that the audience hear the song. We know that in the classical and romantic periods, concerts often follow the long-standing form of classical music salons, usually in courts or music salons, with audiences ranging from 50 to 80 people. Singing art songs requires exquisiteness and exquisiteness. If the opera is shocking, the art songs are often intoxicating. The opera is full of blood, the emotion of the opera is outward, and the emotions of the audience are spewed out; the artistic songs often irritate the emotions, and the emotions are more introverted and penetrate deep into the heart. Therefore, artistic songs are not as grand in volume and intensity as the opera requires, but the requirements for timbre change and control are very particular and need to be carefully crafted. If the opera is good at expressing epic magnificent or emotionally conflicting content, then the art songs are smaller and more adept at expressing subtle, relatively simple and independent emotions. Just like the difference between the big river and the meandering stream, they are very beautiful, but they are different and can touch people, but the way they move is not the same. Just like spring and autumn, the spring blossoms in the spring make us excited, and the fall of the autumn winds in the fall also makes us feel a lot of emotions. The commonality of art is the same, it is to stimulate people's feelings of beauty in the heart, the call of emotion and mutual touch, and personality is the charm of each art form.

With the changes of the times, the artistic songs of each nation are constantly changing. The artistic songs of Richard Strauss, Wolff, Mahler and the German art songs in the romantic period have obvious changes. The works of Sibiki and Chimala

Steve's difference is different, not to mention the earlier Rossini, Donizetti and Bellini. After the reform and opening up, China has witnessed the creation and prosperity of art songs. More works are pursuing great momentum and big scenes. Most of them celebrate the motherland.

Celebrate the nation, sing the hometown, and sing ideals. From the lyrics to the melody to the whole, it tries to show a great power. In the songs with more distinct national styles, it tends to show beauty and simplicity, but the works of elegant and meticulous style are obviously not rich enough. Therefore, we often encounter difficulties in our vocal music teaching. Songs that are sung by students with certain basics are easier to find, while students with lower or lower levels are less able to compete, especially less good songs. I hope that Chinese composers will be able to create excellent vocal works suitable for vocal learning at all stages in the future. At the same time, I hope 
that the research in this paper can make a full contribution to the teaching of vocal music and vocal music in China.

\section{References}

[1] Yu Zizheng. Vocal Music Teaching [M]. Chongqing: Southwest Normal University Press, 2000

[2] Han Xunguo [M]. Vocal Music Foundation. Higher Education Press, 2001

[3] Wu Tianqiu [M]. Make your songs more beautiful. People's Music Publishing House, 1999 